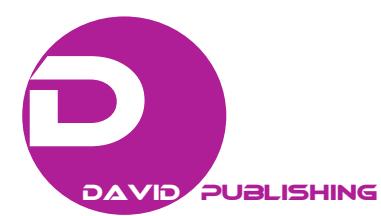

\title{
Evaluation of Curriculum by Progress Test
}

\author{
H. Omer Tontus and Ozlem Midik \\ Department of Medical Education, University of Ondokuz, Mayis, Samsun 55000, Turkey
}

\begin{abstract}
Progress test is a test of the whole learning process. Questions are chosen depending on the complete learning objectives of medical school and this can give opportunity to evaluate curriculum. We aimed to examine the use of progress tests in a matrix table as part of a feedback process to curriculum designer and evaluate the strengths and weaknesses of curriculum. Progress testing was introduced to our students since 2009. We used 200 MCQ single best answer format questions from 40 departments in 11 organ different systems. In total we gathered 713790 answers from students' paper based tests. The Matrix Analyse Table constructed by tagged questions' answers to departments educational activities. Followed by evaluation of departments depending on students' response with predetermined difficulty indexed questions. Answers embedded to the matrix table to take a snapshot of curriculum. In the Matrix Analyse Table, we summarized organ systems in columns and departments in rows. Endocrine \& Metabolism system questions were best correct answers rate while Urogenital System lowest. Infectious Disease Department is rated worst by students' answers as feedback. But by using matrix table, we found infectious disease question, which related respiratory system having good correct rate while cardiovascular infectious disease worst. Such results enable us opportunity to criticize specific point. Our results show that progress testing is a valid and reliable instrument to evaluate effectiveness of departments and divisions in undergraduate medical education. The Matrix Analyse Table gives perfect clues to students and curriculum designers about their strength and weakness.
\end{abstract}

Key words: Progress test, curriculum, evaluation, matrix analyse.

\section{Introduction}

A progress test (PT) is a comprehensive knowledge test which assesses the end objectives of undergraduate medical training as far as knowledge is concerned across all medical disciplines. PT is a test of the whole learning process. In principle, questions are chosen depending on the complete learning objectives of medical school which are considered a requirement for medical students for completion of the undergraduate programme. Over the progression of the programme, students expected to improve their scores on the subsequent test. PT results enabling students and staff to monitor progress [1]. Having adopted Malcolm Knowles adult learning strategies, a requirement also became evident for suitable assessment strategies to test the working knowledge of the students and to fit with the educational philosophies of the curriculum [2].

Corresponding author: H. Omer Tontus, ASS. PROF. Dr., $\mathrm{MD}$, research fields: general surgeon, clinical surgeon, medical education.
With progress testing, the entire student population of a medical school sits the same paper and pencil test [3]. In Maastricht, annually, four progress tests are administered to all students and a single progress test consists of approximately 250 test items of the true/false/don't know format [3].

Although, the number of context-based questions increases, there are still too many progress test questions that focus too much on factual knowledge. We are trying to build up more scenario based contextually rich questions, which promote reasoning and the implementation and interpretation of knowledge [3]. Unlike in the United States, there are no national examinations in undergraduate (but postgraduate) medical education in Turkey. Because of that medical schools in Turkey are in need of dedicated medical teacher for implementing a new test.

Progress testing is a test of the complete domains of knowledge considered a requirement for a medical student on completion of his or her undergraduate course. The whole school sits the same test together at 
intervals during the year and the growth of knowledge of each year group and each individual is mapped over the 5 to 6-year period [1]. Progress test measures the augmentation in knowledge over a time period, but also loosing of knowledge [4]. So much information is needed for a student to become a healthcare professional, medical schools have to create/use specific tools such as progress test to assess the acquisition of knowledge during the educational years. Students have to acquire information continuously in such a way that it will be available when required [2].

The test provides a huge resource for feedback to students, lecturers and for internal and external evaluation [2]. PT more appropriately measure what is actually retained and what is lost in time, giving appropriate feedback for curriculum designer [4]. It helps make the students familiar with the level of knowledge expected at the end of the 5-year programme. In this way, the test is successful in assessing functional knowledge [2, 5]. In any case, PT reduces the attitude of learning for exams, stimulates a deeper learning, and gives logic for learning as a professional, measures long-term knowledge [4]. Most students in the early years have insufficient knowledge to answer most of the questions.

\section{Aim}

In many studies, progress test results provide a huge resource for feedback to students, tutors, advisors and lecturers [2]. We aimed to examine the use of progress tests in a matrix table as part of a feedback process to curriculum designer which summarize all results of tests based on departments and systems. We wanted to evaluate the strengths and weaknesses of the Ondokuzmayis University Medical Faculty (OMU/MF) curriculum through consecutive PTs. Therefore, our objectives were to determine the role of PTs for analysis in developing new curriculum or criticize on-going curriculum. Also progress test gives us focused feedback that is related to the strengths and weaknesses of our medical curriculum.

\section{Material and Methods}

In OMU/MF, progress testing was introduced to our students in the second semester of 2008-09. Although, PT were developed in the USA (University of Missouri Kansas City School of Medicine) and the Netherlands (University of Limburg in Maastricht) almost over 35 years ago [2,3], only two of 78 medical faculties of Turkey are managing PT to evaluate their student and curriculum that are OMU/MF and Ege University Medical Faculty. We decided to apply the test three times in a year at the second half of November, March and May.

Till now, we conducted seven progress tests; one in 2008-09 (G0) three in 2009-10 (G1-G3) and three in 2010-11 (G4-G6) educational years. Our system is PBL based and first three years constructed with 21 blocks which followed by two consecutive years of task based clerkship period. Test questions are prepared by Progress Test Committee which built up with representatives of each blocks and clerkship task groups. Because the target examinee population in this test was medical students of different level, we selected individuals for progress test committee who had close contact and experience with medical students and medical education in their departments. In order to assure that items are not under or over represented within the different departments, the number of questions relating to each block was calculated on the basis of the number of days allotted to that block in the curriculum and collected from representing department in block schedule. This allows appropriate feedback for students and curriculum designer.

The most common question type in Turkey is multiple-choice questions with 5 options. Both teaching staff and students are trained on this type of questions, due to this we decided to use only these MCQs.

Each PT consisted of 200 items of the MCQ single best answer format collected from 40 departments in 11 different systems. Each question tagged with block/task name, organizing department and related 
system. The blueprint is organised by organ systems and departments. The students are asked to take the test in 200 minutes.

"The Matrix Analysis" of four consecutive PTs results inspected to evaluate curriculum design by Department of Medical Education of OMU/MF. The questions scrutinized and results are summarized in two tables by departments and then by organ systems. There after matrix table are formed by conjoining represented tables.

This enabled us to give feedback to student on their rank in their classmate and in all students, their general performance, general knowledge progress, block, organ system and department based performance in particular exam.

We collected 4 PT results in total 800 items all in single best answer MCQs. With representing data, we studied deeply on our curriculum. Test results announced to all individual students with all analysis report. These results give opportunity to check their progress from first PT to last one by themselves. In our study, we tried to give detailed feedback to curriculum designer for future planning.

\section{Results}

We applied "matrix analysis method" to the progress test results of OMU/MF in two academic years (2009/2010-2010/2011), using the data of four consecutive progress tests.

Student numbers who sat on progress tests were different from test to test. Highest attendance was on PT1 (79.1\%) and lowest on PT4 (71.2\%) as shown in Table 1. When highest participation is shown by Year 2 students $(95.3 \%)$, Year 6 students were lowest $(16.1 \%)$.

On the way to produce matrix analysis table, items were grouped by departments firstly (Table 2 ). Some departments are represented only by few questions. Due to this, we grouped them in three different categories which are sensation group, Group 1 and Group 2. Internal Medicine (8.2\%) was the most question provider department. If all questions would have answered by all the attendants, in total we would collected 586,185 option choices or answered questions. But, we have 285,516 (48.7\%) answered question. The highest answer percentage was in sensation group (64.0\%) and the lowest was for Physiology (37.5\%) questions. The highest correct answer rate was for Microbiology (61.5\%) questions and the lowest rate for Infectious Diseases (45.7\%) questions.

Secondly items were grouped by organ system. General Principle \& Cell (25.9\%) was the most question chosen system. The highest correct answer percentage was in "hormones \& metabolism systems" $(58.1 \%)$ and the lowest was for "urinary \& reproductive system" (49.8\%) questions (Table 3).

Overall correct answer percentage was $53.3 \%$ in all students group.

Thereafter, we distributed the tagged questions to related departments and organ systems in a matrix analyse table (Table 3 ). This gave us to chance to take a snapshot of curriculum and deliver detailed feedback to curriculum designer. In table, we summarized organ systems in columns and departments in rows. For example, the cell which digestive system column intersects with internal medicine row represents Gastroenterology division (15 questions 51.00\% correct answer rate by all students group) or the cell which neurosystem column intersect with paediatrics row represents Paediatric Neurology division (3 questions $39.65 \%$ correct answer rate by all students group).

When matrix analysis table completed, students deanery of OMU/MF organized a discussion panel under supervision of Medical Education Department to share result with academic staff. The highest number of question in organ system based structure was represented from general principles \& cell groups by 207 (27.88\%) questions. Psychosocial System (31) and Blood \& Immune system (33) are the two lowest question collected systems. We put the question numbers 
Table 1 Student attendance in the 4 applications of progress testing, according to the school year.

\begin{tabular}{llllllll}
\hline \multirow{2}{*}{ School Year } & $\begin{array}{l}\text { Student } \\
\text { Numbers } \\
\end{array}$ & $\begin{array}{l}\text { Test 1 } \\
n(\%)\end{array}$ & $\begin{array}{l}\text { Test 2 } \\
n(\%)\end{array}$ & $\begin{array}{l}\text { Test 3 } \\
n(\%)\end{array}$ & $\begin{array}{l}\text { Student } \\
\text { Numbers } \\
2010-2011\end{array}$ & $\begin{array}{l}\text { Test 4 } \\
n(\%)\end{array}$ & Total \\
\hline 1 & 242 & $235(97.1)$ & $228(94.2)$ & $221(91.3)$ & 215 & $210(97.7 \%)$ & $894(95.0 \%)$ \\
2 & 157 & $148(94.3)$ & $147(93.6)$ & $148(94.3)$ & 195 & $192(98.5 \%)$ & $635(95.3 \%)$ \\
3 & 127 & $121(95.3)$ & $119(93.7)$ & $121(95.3)$ & 148 & $141(95.3 \%)$ & $502(94.9 \%)$ \\
4 & 139 & $125(89.9)$ & $110(79.1)$ & $67(48.2)$ & 132 & $115(87.1 \%)$ & $417(76.0 \%)$ \\
5 & 168 & $155(92.3)$ & $102(60.7)$ & $78(46.4)$ & 131 & $43(32.8)$ & $378(59.5 \%)$ \\
6 & 163 & $4(2.5)$ & $12(7.4)$ & $89(54.6)$ & 163 & $0(0 \%)$ & $105(16.1 \%)$ \\
\hline Total & 996 & $788(79.1)$ & $718(72.0)$ & $724(72.7)$ & 984 & $701(71.2 \%)$ & 2931 \\
\hline
\end{tabular}

Table 2 Department based analysis of PTs.

\begin{tabular}{|c|c|c|c|c|c|}
\hline Departments & & $\begin{array}{l}\text { Expected Answer in } \\
\text { full }(\%)\end{array}$ & $\begin{array}{l}\text { Left Blank } \\
n(\%)\end{array}$ & $\begin{array}{l}\text { Answers } \\
n(\%)\end{array}$ & $\begin{array}{l}\text { Correct Answers } \\
n(\%)\end{array}$ \\
\hline \multirow{5}{*}{ Basic Science } & Microbiology & $22549(3.8)$ & $12497(55.4)$ & $10052(44.6)$ & $6177(61.5)$ \\
\hline & Biochemistry & $32334(5.5)$ & $13728(42.5)$ & $18605(57.5)$ & $10896(58.6)$ \\
\hline & Anatomy & $43213(7.4)$ & $19044(44.1)$ & 24169 (55.9) & $13631(56.4)$ \\
\hline & $\begin{array}{l}\text { Histology \& } \\
\text { Embryology }\end{array}$ & $21889(3.7)$ & $8844(40.4)$ & 13045 (59.6) & $6864(52.6)$ \\
\hline & Physiology & $43175(7.4)$ & $16179(37.5)$ & $26996(62.5)$ & $14741(54.6)$ \\
\hline \multirow{5}{*}{$\begin{array}{l}\text { Surgical } \\
\text { Sciences }\end{array}$} & Urology & $8776(1.5)$ & $4619(52.6)$ & $4157(47.4)$ & $2069(49.8)$ \\
\hline & Pathology & $28153(4.8)$ & $14438(51.3)$ & 13715 (48.7) & $7750(56.5)$ \\
\hline & Orthopaedics & $11835(2.0)$ & $5478(46.3)$ & $6357(53.7)$ & $3690(58.1)$ \\
\hline & General Surgery & $23162(4.0)$ & $11866(51.2)$ & $11296(48.8)$ & $6281(55.6)$ \\
\hline & Gynaecology \& Obs. & $38932(6.6)$ & $22363(57.4)$ & $16568(42.6)$ & $8379(50.6)$ \\
\hline \multirow{13}{*}{$\begin{array}{l}\text { Clinical } \\
\text { Sciences }\end{array}$} & Pharmacology & $32572(5.6)$ & $16039(49.2)$ & $16533(50.8)$ & 9007 (54.5) \\
\hline & Paediatrics & $32189(5.5)$ & $17768(55.2)$ & $14421(44.8)$ & $7402(51.3)$ \\
\hline & Cardiology & $19636(3.3)$ & $11511(58.6)$ & $8125(41.4)$ & 3857 (47.5) \\
\hline & Internal Medicine & $48072(8.2)$ & $25139(52.3)$ & $22933(47.7)$ & $11651(50.8)$ \\
\hline & Pulmonary Disease & $16121(2.8)$ & $9245(57.4)$ & $6876(42.6)$ & 3279 (47.7) \\
\hline & Emergency & $8916(1.5)$ & 4804 (53.9) & $4112(46.1)$ & $2255(54.8)$ \\
\hline & Infectious Dis. & $20576(3.5)$ & $12611(61.3)$ & 7965 (38.7) & $3641(45.7)$ \\
\hline & Neurology & $27920(4.8)$ & $16288(58.3)$ & $11632(41.7)$ & $5737(49.3)$ \\
\hline & Psychiatry & 21305 (3.6) & $10646(50.0)$ & $10659(50.0)$ & $6103(57.3)$ \\
\hline & $\begin{array}{l}\text { Physical Therapy } \\
\text { \&Rehab. }\end{array}$ & $11000(1.9)$ & 6595 (59.9) & $4405(40.1)$ & $2040(46.3)$ \\
\hline & Sensation Group* & $27781(4.7)$ & $17779(64.0)$ & $10002(36.0)$ & $5300(53.0)$ \\
\hline & GROUP $1 * *$ & $16214(2.8)$ & 7399 (45.6) & $8815(54.4)$ & 4048 (45.9) \\
\hline & GROUP $2 * * *$ & $29865(5.1)$ & 15787 (52.9) & $14078(47.1)$ & $7374(52.4)$ \\
\hline \multicolumn{2}{|l|}{ Total } & 586185 & $300667(51.3)$ & $285516(48.7)$ & $152172(53.3)$ \\
\hline
\end{tabular}

*Sensation Group; Ophthalmology, ENT, Dermatology, **Group 1; Forensic Medicine, Family Medicine, Community Health, Paediatric Psychiatry, Ethics, Nuclear Medicine, Radiation Oncology, Radiology, Medical Biology, Medical Genetics, Biophysics, Biostatistics, ***Group 2; Anaesthesiology \& reanimation, Neurosurgery, Paediatric Surgery, Cardiac Surgery, Thorax Surgery, Plastic \& Reconstructive Surgery. 
Table 3 Matrix analysis of departments and organ systems with question numbers and correct answer percentage.

\begin{tabular}{|c|c|c|c|c|c|c|c|c|c|c|c|c|}
\hline & $\begin{array}{l}\text { Psychosocial } \\
\text { system }\end{array}$ & $\begin{array}{l}\text { Hormon \& } \\
\text { metabol. }\end{array}$ & $\begin{array}{l}\text { General } \\
\text { principl \& } \\
\text { Cell }\end{array}$ & Skin \& Sens. & . Cardiovasculer & Respiratory & Musculoskeletal & Digestive & $\begin{array}{l}\text { Urinary \& } \\
\text { Repro. }\end{array}$ & $\begin{array}{l}\text { Blood \& } \\
\text { immune } \\
\text { system }\end{array}$ & Neurosystem & $\begin{array}{l}\text { Dept. } \\
\text { Question } \\
n \text { (\% Correct } \\
\text { Answer) } \\
\end{array}$ \\
\hline \multicolumn{13}{|l|}{ Basic Science } \\
\hline Microbiology & & & $31(61.45)$ & & & & & & & & & $31(61.45 \%)$ \\
\hline Biochemistry & & 17 (65.95) & $18(49.43)$ & & & & & $2(61.05)$ & & $4(66.69)$ & $3(50.54)$ & $44(58.56 \%)$ \\
\hline Anatomy & & $1(75.35)$ & & $11(55.06)$ & $6(54.75)$ & $2(32.03)$ & $9(48.99)$ & $4(49.64)$ & $8(56.48)$ & & $18(63.03)$ & $59(56.40)$ \\
\hline $\begin{array}{l}\text { Histology \& } \\
\text { Embryology }\end{array}$ & & $1(20.83)$ & $8(65.39)$ & $2(50.83)$ & $3(33.25)$ & $3(56.28)$ & & $1(57.95)$ & $7(38.25)$ & $2(65.26)$ & $3(59.88)$ & $30(52.62)$ \\
\hline Physiology & & $3(58.77)$ & $7(59.50)$ & $2(41.54)$ & $10(67.81)$ & $2(32.04)$ & $7(48.83)$ & $5(37.38)$ & $2(79.37)$ & $6(48.13)$ & $15(49.22)$ & $59(54.60)$ \\
\hline \multicolumn{13}{|l|}{ Surgical Sciences } \\
\hline Urology & & & & & & & & & $12(49.77)$ & & & $12(49.77)$ \\
\hline Pathology & & $1(27.44)$ & $28(56.86)$ & $1(49.16)$ & $4(64.44)$ & $1(54.15)$ & & & & $3(61.53)$ & & $38(56.51)$ \\
\hline Orthopaedics & & & & & & & $16(58.05)$ & & & & & $16(58.05)$ \\
\hline General Surgery & & $6(55.03)$ & $8(57.59)$ & & $1(38.51)$ & $2(54.93)$ & & $15(55.26)$ & & & & $32(55.60)$ \\
\hline $\begin{array}{l}\text { Gynaecology \& } \\
\text { Obs. }\end{array}$ & & $10(57.65)$ & $7(57.34)$ & & & & & & $36(47.12)$ & & & $53(50.57)$ \\
\hline \multicolumn{13}{|l|}{ Clinical Sciences } \\
\hline Pharmacology & $2(60.43)$ & $1(85.88)$ & $22(61.27)$ & & $6(51.09)$ & $3(52.39)$ & $2(35.64)$ & $2(39.92)$ & $3(45.18)$ & $2(22.67)$ & $1(43.68)$ & $44(54.48)$ \\
\hline Paediatrics & & $6(47.61)$ & $20(51.39)$ & $2(71.16)$ & $4(56.76)$ & $3(47.97)$ & $1(86.05)$ & $4(39.70)$ & & $1(30.56)$ & $3(39.65)$ & $44(51.33)$ \\
\hline Cardiology & & & & & $27(47.47)$ & & & & & & & 27 (47.47) \\
\hline $\begin{array}{l}\text { Internal } \\
\text { Medicine }\end{array}$ & & 15 (53.39) & $4(42.11)$ & & $2(42.53)$ & $1(76.87)$ & $5(50.79)$ & $15(51.00)$ & $12(51.71)$ & $12(48.54)$ & & $66(50.80)$ \\
\hline $\begin{array}{l}\text { Pulmonary } \\
\text { Disease }\end{array}$ & & & & & & $22(47.69)$ & & & & & & $22(47.69)$ \\
\hline $\begin{array}{l}\text { Emergency } \\
\text { Medicine }\end{array}$ & & $1(27.40)$ & $8(58.75)$ & & $1(19.13)$ & & & $1(70.09)$ & & & $1(13.74)$ & $12(54.84)$ \\
\hline Infectious Dis. & & & $18(47.46)$ & & & $3(51.32)$ & & $2(28.25)$ & $3(43.55)$ & $1(39.69)$ & $1(37.78)$ & $28(45.71)$ \\
\hline Neurology & & & & & & & & & & & $38(49.32)$ & $38(49.32)$ \\
\hline Psychiatry & $29(57.26)$ & & & & & & & & & & & $29(57.26)$ \\
\hline
\end{tabular}




\begin{tabular}{|c|c|c|c|c|c|c|c|c|c|c|c|c|}
\hline & $\begin{array}{l}\text { Psychosocial } \\
\text { system }\end{array}$ & $\begin{array}{l}\text { Hormon \& } \\
\text { metabol. }\end{array}$ & $\begin{array}{l}\text { General } \\
\text { principl \& } \\
\text { Cell }\end{array}$ & Skin \& Sens. & Cardiovasculer & Respiratory & Musculoskeletal & Digestive & $\begin{array}{l}\text { Urinary \& } \\
\text { Repro. }\end{array}$ & $\begin{array}{l}\text { Blood \& } \\
\text { immune } \\
\text { system }\end{array}$ & Neurosystem & $\begin{array}{l}\text { Dept. } \\
\text { Question } \\
n \text { (\% Correct } \\
\text { Answer) }\end{array}$ \\
\hline $\begin{array}{l}\text { Physical } \\
\text { Therapy } \\
\text { \&Rehab. }\end{array}$ & & & & & & & $15(46.31)$ & & & & & $15(46.31)$ \\
\hline Sensation Group & & & & $36(51.75)$ & & & & & $1(78.56)$ & & $1(47.15)$ & 38 (52.99) \\
\hline GROUP 1 & & & $16(45.06)$ & & $1(13.89)$ & $4(63.15)$ & & & $1(35.26)$ & & & $22(45.92)$ \\
\hline GROUP 2 & & & $12(60.98)$ & $1(62.32)$ & $6(56.93)$ & $6(55.44)$ & $1(62.45)$ & & $1(35.74)$ & $2(28.30)$ & $12(42.20)$ & $41(52.38)$ \\
\hline $\begin{array}{l}\text { SYSTEM } \\
\text { SUMMARY } \\
\text { n }(\% \text { Correct })\end{array}$ & $31(57.39)$ & $62(58.12)$ & $\begin{array}{l}207 \\
(55.80)\end{array}$ & $55(53.28)$ & $71(53.31)$ & $52(50.62)$ & $56(51.73)$ & $51(50.31)$ & $86(49.78)$ & $33(50.31)$ & $96(51.20)$ & $800(53.30)$ \\
\hline
\end{tabular}


and correct answer rate of students together in one cell to avoid under or over criticising of departments/divisions. Some divisions represented with only one or two question need to be evaluate later when appropriate question number reached by more PTs.

\section{Discussion}

The main idea of our current study is the use of "gathered information from progress test" to investigate the effects of curriculum on medical education. Implementation of progress testing at OMU/MF was easier than expected. We have some different approach to PT, as Freeman at al noticed in their review that the PT concept is implemented differently around the world like yearly number of test, question type or number of items [6]. Little complaints received by the Year 1 and 2 students related to their fear that a new methods of test which including all years learning objectives and new assessment model for progression to the next year.

Many researchers noted that knowledge is an essential factor in medical competence [7]. With the same point of view, assessing the knowledge thorough valid and reliable instrument is essential for medical education. Like many other academics, we believe that PT is one of the best assessment methods of recent years.

The use of progress testing is not restricted to PBL programmes or to a single institution. In any medical curriculum knowledge is an important part of competence and thus requires assessment, regardless of the instructional format used [3, 8]. While some researchers indicate that true/false items have some intrinsic disadvantages and there is agreement that simple single best answer or matching items offer better alternatives, others prefer open-ended, short answer questions [9]. Difference from Maastricht is that since very first we do not have any item with "true or false" type in any PT, we used multiple-choice questions, as used by McMaster University and Sao
Paolo University [5, 10]. We are trying to build up more scenario based contextually rich questions, which stimulate "reasoning, implementation and interpretation of knowledge". But produce such a questions require intensive training of staff, since all efforts to produce this type questions have resulted with inadequate success and the tendency of most authors is to produce recall-type test items [3].

There are some limitations and these need to be considered. First of all, the format of the test, with 200 questions, means that some departments are represented only by few questions such as biophysics and medical ethics because of their limited hourly representation in the medical curriculum. If the question is inadequate to the evaluation of the department could produce subjective results [10]. We tried to solve this problem by collecting question directly from relevant department with spare questions. For example, if any department with 4 questions limit in any particular PT, this department sent 6 questions to PT Committee and the committee chose any 4 of them. Another limitation is that the data is not being representative of all the students because of the low attendance of the final year students which the test is not mandatory.

Researchers state that progress testing enables observing of the students' knowledge progression over time by comparing the subsequent similar test results which taken periodically [11]. When some medical school use progress testing just curriculum evaluation, others use simply in order to give feedback to students [12]. We used PT results in both ways. Ricketts et al summarized the types of information under 6 groups which are produced by PT results [13]. Beside of these, depending on our study results we can add two important information groups which PTs allow us about our curriculum such as: (1) Average student response to "organ systems based" test items to evaluate integrated educational framework; (2) Average student response to individual "department based" test items to evaluate the success of departments 
in order to reach learning objectives.

We have similar approach to end learning objectives such as Muijtjens et al is noted in their publication [11]. Although there is standardization of end learning objectives of medical education in Turkey since 2002 which targeted 407 disease and symptom groups in undergraduate medical education, the curriculum of the medical schools are different. Due to this, medical schools have to evaluate their educational end results as students' knowledge level with PTs or similar instruments.

Organ systems list is similar with Nouns et al [14] and Muijtjens et al [11] used in their research. For example in the Netherlands multi-centre PT test, Internal Medicine department provided question number is the highest like our test format [11]. We wanted to evaluate the strengths and weaknesses of the OMU/MF curriculum through consecutive PTs. However, it was difficult to find out the role of the PTs to use in curriculum analysis.

The time and effort to produce valid and reliable test items in acceptable quality is a very difficult job to do. The quality and validity of any test depends on a careful, systematic construction process [3].

Rapid changing and increasing information in medical education puts on pressure to medical teacher to build a curriculum which deliver the required knowledge to students in order to graduate competent healthcare professional. We couldn't find any published documents about analysis of curriculum with progress test. This is the first study about matrix analysis curriculum in Turkey.

\section{Conclusion}

In conclusion, our results show that progress testing is a valid and reliable instrument to evaluate effectiveness of departments in undergraduate medical education. Like many other academics, we believe that PT is one of the best assessment methods of recent years. Comparative studies of medical schools or collaborative progress testing with a group of medical schools with different curriculum using the same instrument possible could contribute to our findings. These kinds of studies are having a very important role for the curriculum designer as summarized feedback methods. Quality in medical education at a national level can be reached by collaborative evaluative studies of different curricula by focusing end learning objectives and results probably will put on pressure for curriculum changes.

\section{Acknowledgement}

Author thank to PT Committee of medical faculty.

\section{References}

[1] McHarg, J., Bradley, P., Chamberlain, S., Ricketts, C., Searle, J., and McLachlan, J. C. 2005. "Assessment of Progress Tests.” Medical Education 39: 221-7.

[2] van der Vleuten, C. P. M., Verwijnen, G. M., and Wijnen, H. F. W. 1996. "Fifteen Years of Experience with Progress Testing in a Problem-Based Learning Curriculum." Medical Teacher 18: 103-9.

[3] van der Vleuten, C. P. M., Schuwirth, L. W. T., Muijtjens, A. M. M., Thoben, A. J. N. M., Cohen-Schotanus, J., and van Boven, C. P. A. 2004. "Cross Institutional Collaboration in Assessment: A Case on Progress Testing." Medical Teacher 26 (8): 719-25.

[4] Vantini, I., and Benini, L. 2008. "Models of Learning, Training and Progress Evaluation of Medical Students." Clinica Chimica Acta 393: 13-6.

[5] Blake, J. M., Norman, G. R., Keane, D. R., Mueller, B., Cunningham, J., and Didyk, N. 1996. "Introducing Progress Testing in McMaster University's Problem-Based Learning Medical Curriculum: Psychometric Properties and Effect on Learning." Academic Medicine 71: 1003-7.

[6] Freeman, A. C., van der Vleuten, C. P. M., Nouns, Z., and Ricketts, C. 2010. "Progress Testing Internationally." Medical Teacher 32: 451-5.

[7] Verhoeven, B. H., Verwijnen, G. M., Scherpbier, A. J., and van der Vleuten, C. P. M. 2002. "Growth of Medical Knowledge." Medical Education 36: 711-7.

[8] Norman, G. R. 1991. "What Should Be Assessed." in The Challenge of Problem-Based Learning, edited by Boud, D., and Feletti, G. New York: St. Martin's Press, 254-9.

[9] Rademakers, J., Ten Cate, T. J., and Bar, P. R. 2005. "Progress Testing with Short Answer Questions." Medical Teacher 27 (7): 578-82.

[10] Tomic, E. R., Martins, M. A., Lotufo, P. A., and Benseñor, I. M. 2005. "Progress Testing: Evaluation of Four Years of 
Application in the School of Medicine, University of São Paulo." Clinics 60 (5): 389-96.

[11] Muijtjens, A. M. M., Schuwirth, L. W. T., Cohen-Schotanus, J., and van der Vleuten, C. P. M. 2008.

"Differences in Knowledge Development Exposed by Multi-Curricular Progress Test Data." Advance in Health Science Education 13: 593-605.

[12] Ricketts, C., and Moyeed, R. 2011. "Improving Progress
Test Score Estimation Using Bayesian Statistics." Medical Education 45: 570-7.

[13] Ricketts, C., Freeman, A., Pagliuca, G., Coombes, L., and Archer, J. 2010. "Difficult Decisions for Progress Testing: How Much and How Often?" Medical Teacher 32: 513-5.

[14] Nouns, Z. M., and Georg, W. 2010. "Progress Testing in German Speaking Countries." Medical Teacher 32: 467-70. 